\title{
Social security expenses with patients with back pain by the National Institute of Social Security of Brazil from 2008 to 2014
}

\author{
Gastos previdenciários com lombalgia pelo Instituto Nacional de Seguro Social (INSS) no \\ Brasil durante o período de 2008 a 2014
}

Gastos previdenciarios con lombalgía por el Instituto Nacional de Seguro Social (INSS) en

Brasil durante el periodo de 2008 a 2014

Marcelo José da Silva de Magalhães ${ }^{1 *}$, Samara Aparecida Martins Dias Silva ${ }^{2}$, Fernando Ericson Almeida Vieira², Samuel Caires Martins de Lima², Thais Mendes Colares Maurício², Thamara de Souza Vieira ${ }^{2}$, Henrique Nunes Pereira Oliva ${ }^{3}$.

\section{ABSTRACT}

Objective: To analyze all social security expenditures paid by Brazilian Institute of Social Security (INSS) of lower back pain, from 2008 to 2014. Methods: Consultation to Social Security database in order to obtain information about the main benefits offered individuals by the INSS, in the period between 2008 and 2014 . Based on the Social Security database and the ICDs M51 and M54, the INSS expenditures were assessed for low-income retirement, sickness and to accidental retirement, between men and women from urban and rural areas from 2008 to 2014. Results: In this period, the most prevalent benefit was Disease Aid, with an average annual cost of $\mathrm{R} \$ 88.458 .511,10$. The total cost of benefit was: Accidental Sickness Insurance-R $\$$ 116.076.692,00;Accidental Retirement-R \$ 6.740.052,84; Illness Assistance-R \$ 373.547.294,00; Retirement Due to Disability-R $\$ 75.883 .844,00$. Among all the above mentioned beneficiaries, there was a predominance of males and individuals living in the urban area. Conclusions: Lower back pain leads to suffering for workers, costs to companies, as well as burdening the public coffers regarding the social security system and health care.

Keywords: Low back pain, Social security, Costs.

\section{RESUMO}

Objetivo: Analisar todos os gastos previdenciários pagos pelo INSS decorrentes de lombalgia, no período de 2008 a 2014. Metodologia: Consulta ao banco de dados da Previdência Social a fim de obter informações referentes aos principais benefícios ofertados aos portadores de lombalgias pelo INSS, levando em conta o período compreendido entre 2008 e 2014. Com base no banco de dados da Previdência Social e nos CID's M51 e M54, foram avaliados os gastos, pelo INSS, com lombalgia referente à aposentadoria por invalidez, ao auxílio doença, auxílio doença acidentária e à aposentadoria acidentária, entre homens e mulheres de zona urbana e rural no período de 2008 a 2014. Resultados: Neste período, o benefício mais prevalente foi o auxílio doença, com gasto médio anual de $\mathrm{R} \$ 88.458 .511,10$. O gasto total por benefício foi: Auxílio doença acidentária-R\$ 116.076.692,00; Aposentadoria acidentária- $\mathrm{R} \$ 6.740 .052,84,00$; Auxílio doença-R $\$$ 373.547,294,00; Aposentadoria por invalidez- R $\$ 37.941 .922,00$. Dentre todos os beneficiários supracitados houve um predomínio do sexo masculino e de indivíduos residentes na zona urbana. Conclusão: A lombalgia acarreta sofrimento aos trabalhadores, custos às empresas, além de onerar os cofres públicos quanto ao sistema previdenciário e de assistência à saúde.

Descritores: Lombalgia, Previdência social, Custos.

\footnotetext{
${ }^{1}$ Neurosurgeon and surgeon of peripheral nerves. Hospital Aroldo Tourinho, Montes Claros - MG, Brazil, Vila da Serra Hospital, Nova Lima-MG, Brazil. *E-mail: marcelo7779@yahoo.com.br

${ }^{2}$ Medical student, Faculdades Unidas do Norte de Minas (FUNORTE), MG

${ }^{3}$ Medical student and Master of Science in Mechanical Engineering, Fac. Integradas Pitágoras de Montes Claros (FIPMoc)
} 


\section{RESUMEN}

Objetivo: Analizar todos los gastos previsionales pagados por el INSS resultantes de lumbar, en el período de 2008 a 2014. Metodología: Consulta al banco de datos de la Previsión Social a fin de obtener informaciones referentes a los principales beneficios ofrecidos a los portadores de lombalgias por el INSS, llevando en, el período comprendido entre 2008 y 2014. Con base en el banco de datos de la Seguridad Social y en los CID's M51 y M54, se evaluaron los gastos, por el INSS, con lumbago referente a la jubilación por invalidez, a la ayuda enfermedad, auxilio enfermedad accidental y en el período de 2008 a 2014. Resultados: En este período, el beneficio más prevalente fue el auxilio enfermedad, con gasto promedio anual de $\mathrm{R} \$$ 88.458.511,10. El gasto total por beneficio fue: Auxilio enfermedad accidental -R $\$ 116.076 .692,00$; Jubilación accidental-R \$ 6.740.052,84,00; Ayuda enfermedad-R \$373.547,294,00; Jubilación por invalidez -R\$ 37.941.922,00. De entre todos los beneficiarios citados hubo un predominio del sexo masculino y de individuos residentes en la zona urbana. Conclusión: La lumbalgia acarrea sufrimiento a los trabajadores, costos a las empresas, además de onerar las arcas públicas en cuanto al sistema previsional y de asistencia a la salud.

Descriptores: Lumbago, Seguridad Social, Costos.

\section{INTRODUCTION}

In Brazil, Social Security aims to provide for its beneficiaries financial help, in front of incapacity, involuntary unemployment, old age, time of service, family expenses, and the death or imprisonment of those on whom they depend economically. The General Social Security System - RGPS - cover pensions, as well as social security benefits classified as: sickness, confinement and accident aid. In the context of social security, there is a deep debate that comes from a great concern of governments around the world, especially Brazil: the sustainability of Social Security systems. This, established under a distribution system, has become an increasing source of expenses for the Federal Government (CORDEIRO, 2006).

In this context, low back pain has been considered a serious public health problem, as it affects a large part of the economically active population, temporarily and even permanently incapacitating it for physical and professional activities (REIS et al, 2003).

Low back pain is defined as any and all pain or stiffness conditions located in the lower back region, located between the last costal arch and the gluteal fold (MADEIRA et al, 2013).It is a condition that can reach up to $65 \%$ of people annually and up to $84 \%$ of people at some point in life, presenting a punctual prevalence of approximately $11.9 \%$ in the world population (WALKER, 2000; HOY et al, 2012). However, these values may be underestimated since less than $60 \%$ of people with low back pain look for treatment. Several risk factors are known, such as sociodemographic characteristics (male sex, low income), health status, lifestyle or behavior (smoking, eating and physical inactivity) and occupation (heavy physical work, repetitive motions) (FERREIRA et al, 2010).

The amount of resources and time spent with people with this type of morbidity is great, being more costly to the public and private coffers to keep the professional productivity away, to invest in an adequate rehabilitation treatment (ABREU e RIBEIRO, 2010).

Given this, the economic impact of low back pain on health and disability compensation systems, is surprising. Despite improvements in diagnostic and therapeutic strategies for low back pain, use of medical services and compensation claims are increasing (DEYO et al, 1991).

The objective of this paper is to prioritize the evaluation of social security expenditures with low back pain in Brazil, as well as discuss the expenses with the benefits of the General Social Security System. 


\section{METHODS}

This article is a descriptive and retrospective study with data collection and quantitative analysis. The databases were the records of the Single System of Benefit Information of the National Institute of Social Security (INSS) and the Statistical Yearbooks of Social Security. The pathology analysis was performed based on the data from 2008 to 2014, in the Social Security system, according to the ICD-10 ICD-BR Tabulation List, that is, M54 and M51. The sample consisted of lumbago registries between January 2008 and December 2014 , with a special focus on epidemiological data and costs in Brazilian Reais ( $R \$$ ). The databases were tabulated through descriptive statistics with the Microsoft Office Excel 2007 Package. The study did not require the approval of the Research Ethics Committee due to the open data character that makes it impossible to identify the subjects, according to Resolution 466 / 12 of the National Health Council.

The following categories of benefits offered by the government were analyzed, covering the years 2008 to 2014: disability retirement, sickness benefits, accident sickness insurance and accident retirement.

The evaluation of the data, as well as the preparation of the tables, was produced based on the amount spent annually, in reais and in dollars, also discriminating number of beneficiaries by sex, type of benefit and area of residence, according to INSS data.

\section{RESULTS}

Table 1 shows the total social security expenditures with low back pain in Brazil, from 2008 to 2014, for ICD 10: M54 (dorsalgia) and M51 (other intervertebral disc disorders), by gender, urban and rural areas. In the period studied, according to the social security and data surveyed, there was a considerable increase in expenses and number of individuals, except in the period between 2008 and 2009 and 2012 and 2013, in which there was a drop in the cited criteria.

It can be inferred from Table 1 that men accounted for $81 \%$ of total social security expenditures with low back pain, the highest in the urban area, totaling $R \$ 1.206 .316 .134,00$ (US $\$ 386.602 .607,26$ ) to the detriment of the rural area, which was $\mathrm{R} \$ 66.062 .426,00$ (US $\$ 21.171 .818,41$ ). According to the annual social security statistics, the year 2008 demanded higher public spending, $R \$ 728.016 .886,00$ (US $\$ 2.277 .884 .441,70$ ), among all the years studied, in which also the highest percentage $(96.8 \%)$ of spending on urban men.

In this same study, the total number of beneficiaries was 1.476 .414 of which $59 \%$ were male and $41 \%$ were female. The annual average of benefits analyzed corresponds to $R \$ 1,051.93$ per individual and the total average of beneficiaries, considering the entire period from 2008 to 2014, was $R \$ R \$ 1.553 .094 .158,00$ (US $\$$ $2,673,963,634.91)$, covering both sexes, urban and rural area.

According to data from Table 2, we can infer that the accidental illness aid was the second modality that demanded higher social security expenditures due to low back pain in this period. We can also conclude that there was an average of expenses between 2008 and 2014 of $R \$ 33.164 .769,14$ (US\$ 10.628.711,54), with 2008 being the one with the highest expenditure, representing $17 \%$ of the total. In addition, expenditure has been reduced over the years, with the exception of 2012 to 2013 , which saw a $33 \%$ increase. Regarding the number of individuals, a regression of approximately $50 \%$ was observed (from 52.869 to 26.390), from the beginning to the end of the period studied in this present study. Besides that, the cost reduced, but not in the same proportion (from $39.552 .081,00$ to $30.309 .777,00$ ), possibly due to inflation.

From the analysis made, Table 3 shows that the accidental retirement benefit burdened the public coffers, a total amount of $R \$ 33.737 .627,00$ (US $\$ 10.812 .302,18$ ), being the kind of least monetary expenditure in Brazil. This table also shows that, in the year of 2012, a benefit for accident was granted to a greater number of people (1894), but the largest expenses were related to the years $2013(R \$ 23.700 .480,00$ or $7.595 .577,23$, in dollars), in which 1818 people were granted the benefit. In comparison to other benefits, this species did not show a steady increase in spending and the number of beneficiaries (increased every year from 2008 until 2012 and decreased the number of people from 2012 to 2014). 
Table 1: Expenses with lombalgia in brazil in the years of 2008-2014 CID M 54 and M51

\begin{tabular}{|c|c|c|c|c|c|c|c|}
\hline Year & Area & Gender & Number of beneficiaries & & Value r\$ & & ${ }^{*}$ value us\$ \\
\hline \multirow{4}{*}{2008} & \multirow{2}{*}{ Urban } & Male & 184.446 & $\mathrm{R} \$$ & $705.384 .786,00$ & $\$$ & 2.260.631.260,99 \\
\hline & & Female & 80.328 & $\mathrm{R} \$$ & $12.910 .883,00$ & $\$$ & 4.137.705,61 \\
\hline & \multirow{2}{*}{ Rural } & Male & 14.015 & $\mathrm{R} \$$ & $5.744 .739,00$ & $\$$ & $1.841 .085,45$ \\
\hline & & Female & 9.700 & $\mathrm{R} \$$ & $3.976 .478,00$ & $\$$ & $1.274 .389,62$ \\
\hline & TOTA & & 288489 & $\mathbf{R} \$$ & 728.016 .886 .00 & $\$$ & 2.267.884.441,70 \\
\hline \multirow{4}{*}{2009} & \multirow{2}{*}{ Urban } & Male & 99.493 & $\mathrm{R} \$$ & $74.072 .821,00$ & $\$$ & $23.739 .005,82$ \\
\hline & & Female & 66.675 & $\mathrm{R} \$$ & $35.286 .298,00$ & $\$$ & $11.308 .623,36$ \\
\hline & \multirow{2}{*}{ Rural } & Male & 12.243 & $\mathrm{R} \$$ & $5.651 .454,00$ & $\$$ & $1.811,189,28$ \\
\hline & & Female & 8.123 & $\mathrm{R} \$$ & $3.749 .604,00$ & $\$$ & $1.201 .680,59$ \\
\hline & TOTA & & 186.534 & $\mathbf{R} \$$ & $118.760 .177,00$ & $\$$ & $38.060 .499,05$ \\
\hline \multirow{4}{*}{2010} & \multirow{2}{*}{ Urban } & Male & 100.557 & $\mathrm{R} \$$ & $77.910 .737,00$ & $\$$ & $24.968 .988,82$ \\
\hline & & Female & 71.455 & $\mathrm{R} \$$ & $40.058 .166,00$ & $\$$ & $15.676 .784,36$ \\
\hline & \multirow{2}{*}{ Rural } & Male & 12.948 & $\mathrm{R} \$$ & $6.595 .803,00$ & $\$$ & $137.948 .007,86$ \\
\hline & & Female & 8.615 & $\mathrm{R} \$$ & $4.388 .864,00$ & $\$$ & $1.406 .551,91$ \\
\hline & TOTA & & 193.575 & $\mathbf{R} \$$ & $128.953,570,00$ & $\$$ & $180.000 .329,95$ \\
\hline \multirow{4}{*}{2011} & \multirow{2}{*}{ Urban } & Male & 101.755 & $\mathrm{R} \$$ & $82.630 .583,00$ & $\$$ & $26.292 .225,02$ \\
\hline & & Female & 74.279 & $\mathrm{R} \$$ & $43.930 .695,00$ & $\$$ & $14.080 .727,60$ \\
\hline & \multirow{2}{*}{ Rural } & Male & 8.835 & $\mathrm{R} \$$ & $6.816 .551,00$ & $\$$ & $2.170 .160,21$ \\
\hline & & Female & 8.307 & $\mathbf{R} \$$ & $4.823 .770,00$ & $\$$ & $1.448 .838,23$ \\
\hline & TOTA & & 193.176 & $\mathbf{R} \$$ & $138.201 .599,00$ & $\$$ & $43.991 .951,06$ \\
\hline \multirow{4}{*}{2012} & \multirow{2}{*}{ Urbana } & Masculino & 101.082 & $\mathrm{R} \$$ & $86.752 .410,00$ & $\$$ & $27.802 .585,86$ \\
\hline & & Female & 77.061 & $\mathrm{R} \$$ & $40.406 .432,00$ & $\$$ & $15.833 .872,14$ \\
\hline & \multirow{2}{*}{ Rural } & Male & 12.356 & $\mathrm{R} \$$ & 25.697.292,00 & $\$$ & $8.634 .102,32$ \\
\hline & & Female & 8.601 & $\mathrm{R} \$$ & $5.349 .822,00$ & $\$$ & $1.714 .521,66$ \\
\hline & TOTA & & 199.100 & $\mathbf{R} \$$ & $158.205 .956,00$ & $\$$ & $53.985 .081,98$ \\
\hline \multirow{4}{*}{2013} & \multirow{2}{*}{ Urbana } & Male & 101.869 & $\mathrm{R} \$$ & $93.041 .112,00$ & $\$$ & $29.818 .001,66$ \\
\hline & & Female & 82.729 & $\mathrm{R} \$$ & $12.855 .420,00$ & $\$$ & 4.119.930,72 \\
\hline & \multirow{2}{*}{ Rural } & Male & 12.400 & $\mathrm{R} \$$ & $8.409 .231,00$ & $\$$ & 2.695.007,17 \\
\hline & & Female & 8.850 & $\mathrm{R} \$$ & $5.998 .508,00$ & $\$$ & $1.922 .413,84$ \\
\hline & TOTA & & 205.848 & $\mathbf{R} \$$ & $120.304 .271,00$ & $\$$ & $38.555 .353,39$ \\
\hline \multirow{4}{*}{2014} & \multirow{2}{*}{ Urbana } & Male & 100.554 & $\mathrm{R} \$$ & $86.523 .685,00$ & $\$$ & $27.729 .283,62$ \\
\hline & & Female & 86.856 & $\mathrm{R} \$$ & $60.467 .037,00$ & $\$$ & $19.378 .596,94$ \\
\hline & \multirow{2}{*}{ Rural } & Male & 13.077 & $\mathrm{R} \$$ & 7.147 .356 .00 & $\$$ & $2.290 .598,94$ \\
\hline & & Female & 9.205 & $\mathrm{R} \$$ & $6.513 .621,00$ & $\$$ & $2.087 .498,28$ \\
\hline $\begin{array}{c}\text { TOTAL } \\
\text { GRAND TOTAL }\end{array}$ & \multicolumn{2}{|c|}{ TOTAL } & $\begin{array}{c}209.692 \\
1476.414,00\end{array}$ & $\begin{array}{c}\mathbf{R} \$ \\
\mathbf{R} \mathbf{1}\end{array}$ & $\begin{array}{c}160.651 .699,00 \\
553.094 .158,00\end{array}$ & $\$$ & $\frac{51.485 .977,78}{73.963 .634,91}$ \\
\hline
\end{tabular}

** Value considering quotation on 05/09/2017 (1 REAL / BRL (790) = USD 0,320482 (220)) Source: DATASUS- www4.bcb.gov.br/pec/conversao/conversao.asp. 
Table 2: SOCIAL SECURITY EXPENSES WITH LOMBALGIA IN BRAZIL - CID M51 and M54 SPECIES: ACCIDENTAL DISEASE AID

\begin{tabular}{|c|c|c|c|}
\hline YEAR & NUMBER OF BENEFICIARIES & VALUE IN REAIS (R\$) & VALUE IN DOLLARS (US\$) \\
\hline $\mathbf{2 0 0 8}$ & 52.869 & $\mathrm{R} \$ 39.552 .081,00$ & $\$ 12.675 .730,02$ \\
\hline $\mathbf{2 0 0 9}$ & 43.058 & $\mathrm{R} \$ 34.869 .054,00$ & $\$ 11.174 .904,16$ \\
\hline $\mathbf{2 0 1 0}$ & 36.987 & $\mathrm{R} \$ 31.972 .257,00$ & $\$ 10.246 .532,87$ \\
\hline $\mathbf{2 0 1 1}$ & 34.420 & $\mathrm{R} \$ 31.896 .373,00$ & $\$ 10.222 .213,41$ \\
\hline $\mathbf{2 0 1 2}$ & 31.412 & $\mathrm{R} \$ 31.277 .310,00$ & $\$ 10.023 .814,86$ \\
\hline $\mathbf{2 0 1 3}$ & 30.150 & $\mathrm{R} \$ 32.276 .532,00$ & $\$ 10.334 .047,53$ \\
\hline $\mathbf{2 0 1 4}$ & 26.390 & $\mathrm{R} \$ 30.309 .777,00$ & $\$ 9.713 .737,95$ \\
\hline TOTAL & $\mathbf{2 5 5 . 2 8 6}$ & $\mathbf{R} \$ \mathbf{2 3 2 . 1 5 3 . 3 8 4 , 0 0}$ & $\mathbf{\$ 7 4 . 3 9 0 . 9 8 0 , 8 0}$ \\
\hline
\end{tabular}

Source: DATASUS- $\underline{w w w 4 . b c b . g o v . b r / p e c / c o n v e r s a o / c o n v e r s a o . a s p}$.

Table 3: PREVENTIONAL EXPENSES WITH LOMBALGIA IN BRAZIL - CID M51 and M5 SPECIES: ACIDENTARY RETIREMENT

\begin{tabular}{|cccc} 
YEAR & NUMBER OF BENEFICIARIES & VALUE IN REAIS (R\$) & VALUE IN DOLLARS (US\$) \\
\hline $\mathbf{2 0 0 8}$ & 1.187 & $\mathrm{R} \$ 1.193 .912,00$ & $\$ 382.627,31$ \\
$\mathbf{2 0 0 9}$ & 1.456 & $\mathrm{R} \$ 496.188,00$ & $\$ 159,019,32$ \\
\hline $\mathbf{2 0 1 0}$ & 1.791 & $\mathrm{R} \$ 1.908 .227,00$ & $\$ 611,552,41$ \\
\hline $\mathbf{2 0 1 1}$ & 1.834 & $\mathrm{R} \$ 2.095 .221,00$ & $\$ 671.480,62$ \\
\hline $\mathbf{2 0 1 2}$ & 1.894 & $\mathrm{R} \$ 2.267 .950,00$ & $\$ 726.837,15$ \\
\hline $\mathbf{2 0 1 3}$ & 1.818 & $\mathrm{R} \$ 23.700 .480,00$ & $\$ 7.595 .577,23$ \\
\hline $\mathbf{2 0 1 4}$ & 1.529 & $\mathrm{R} \$ 2.075 .649,00$ & $\$ 665.208,14$ \\
\hline TOTAL & $\mathbf{1 1 5 0 9}$ & $\mathbf{R} \$ \mathbf{3 3 . 7 3 7 . 6 2 7 , 0 0}$ & $\mathbf{\$ 1 0 . 8 1 2 . 3 0 2 , 1 8}$ \\
\hline
\end{tabular}

Source: DATASUS- www4.bcb.gov.br/pec/conversao/conversao.asp. 
Table 4: POVERTY EXPENSES WITH LOMBALGIA IN BRAZIL - CID M51 and M54 SPECIES: DISEASE AID

\begin{tabular}{|cccc}
\hline YEAR & $\begin{array}{c}\text { NUMBER OF } \\
\text { BENEFICIARIES }\end{array}$ & VALUE IN REAIS (R\$) & VALUE IN DOLLARS (US\$) \\
\hline $\mathbf{2 0 0 8}$ & 156.520 & $\mathrm{R} \$ 77.028 .519 .00$ & $\$ 24.686 .253,83$ \\
$\mathbf{2 0 0 9}$ & 131.355 & $\mathrm{R} \$ 72.473 .758 .00$ & $\$ 23.226 .534,91$ \\
\hline $\mathbf{2 0 1 0}$ & 139.905 & $\mathrm{R} \$ 85.027 .836 .00$ & $\$ 27.249 .890,94$ \\
\hline $\mathbf{2 0 1 1}$ & 150.787 & $\mathrm{R} \$ 93.683 .601 .00$ & $\$ 30.023 .907,82$ \\
$\mathbf{2 0 1 2}$ & 156.200 & $\mathrm{R} \$ 104.676 .657 .00$ & $\$ 33.546 .984,39$ \\
$\mathbf{2 0 1 3}$ & 164.513 & $\mathrm{R} \$ 118.037 .684 .00$ & $\$ 37.828 .953,04$ \\
\hline $\mathbf{2 0 1 4}$ & 172.870 & $\mathrm{R} \$ 196.166 .531 .00$ & $\$ 62.867,842,19$ \\
\hline TOTAL & $\mathbf{1 . 0 7 2 . 1 5 0}$ & $\mathbf{R} \mathbf{6} \mathbf{6 1 9 . 2 0 9 . 5 7 8 , 0 0}$ & $\mathbf{\$} \mathbf{1 9 8 . 4 4 5 . 5 2 3 , 9 8}$ \\
\hline
\end{tabular}

Source: DATASUS- www4.bcb.gov.br/pec/conversao/conversao.asp.

The benefit that presented the highest expenses was the sickness benefit (Table 4), totaling a value of $\mathrm{R} \$$ 616.209.578,00 (US \$ 198.445.523,98). The highest expenditure was obtained in 2014, which was also the year with the greatest benefits granted, representing $16 \%$ of the total, in relation to the study of the species and $39 \%$ of the total expenses analyzed by this work. Social security shows a progression in expenses and benefits granted from 2009, approximately tripling the amount (from 24.686.253,83 dollars and 131.355 beneficiaries in 2009 to $62.867 .842,19$ dollars and 172.870 beneficiaries in 2014).

The retirement granted after finding incapacity (disability retirement) of the social security medical expertise presented a total expense of $R \$ 75.883 .844,00$ (US $\$ 24.319 .406,09$ ). (Table 5) It should be noted that the year 2008 exempted more expenses and contradictorily the following year, 2009, showed a smaller decrease, making the year with the lowest financial impact. It is also inferred that there is a lack of linearity in the amounts of benefits granted over the years and a tenuous increase in expenses.

Thus, there is no compatible relationship between the increase in expenses and the number of benefits granted, as occurs between 2009 and 2012, in which there is a reduction in the number of individuals contemplated and an increase in the social security deficit.

Table 5: POVERTY EXPENSES WITH LOMBALGIA IN BRAZIL - CID M51 and M54 SPECIES: DISABILITY RETIREMENT

\begin{tabular}{lcll} 
YEAR & NUMBER OF BENEFICIARIES & VALUE IN REAIS (R\$) & VALUE IN DOLLARS (US\$) \\
$\mathbf{2 0 0 8}$ & 12.895 & $\mathrm{R} \$ 12.213 .309,00$ & $\$ 3.914 .145,69$ \\
$\mathbf{2 0 0 9}$ & 10.639 & $\mathrm{R} \$ 9.920 .696,00$ & $\$ 3.179 .404,50$ \\
$\mathbf{2 0 1 0}$ & 9.894 & $\mathrm{R} \$ 10.045 .200,00$ & $\$ 3.219 .305,79$ \\
$\mathbf{2 0 1 1}$ & 9.735 & $\mathrm{R} \$ 10.183 .844,00$ & $\$ 3.263 .738,69$ \\
$\mathbf{2 0 1 2}$ & 9.594 & $\mathrm{R} \$ 10.960 .889,00$ & $\$ 3.512 .767,63$ \\
$\mathbf{2 0 1 3}$ & 108.555 & $\mathrm{R} \$ 11.283 .309,00$ & $\$ 3.616 .097,43$ \\
$\mathbf{2 0 1 4}$ & 8.903 & $\mathrm{R} \$ 11.276 .597,00$ & $\$ 3.613 .946,36$ \\
\hline TOTAL & $\mathbf{1 7 0 . 2 1 5}$ & $\mathbf{R} \mathbf{7} \mathbf{7 5 . 8 8 3 . 8 4 4 , 0 0}$ & $\mathbf{2 4 . 3 1 9 . 4 0 6 , 0 9}$ \\
\hline
\end{tabular}

Source: DATASUS- www4.bcb.gov.br/pec/conversao/conversao.asp. 


\section{DISCUSSION}

The Global Burden of Disease Study (GBD), published at the end of 2012 by the Institute of Metrics and Health Assessment (IHME), University of Washington - USA, highlighted the enormous global burden of low back pain. In 2010, it ranked first as a cause of disability worldwide, reaching both developed and developing countries and being responsible for 58.2 million years of disability in the population in 1990, rising to 83 million in 2010 (INSTITUTO DE MÉTRICA E AVALIAÇÃO EM SAÚDE, 2013).Of the 21 regions in the world evaluated in the study, low back pain is the first cause of disability in 12 regions, among them the southern region of Latin America (BUCHBINDER et al 2013). With the sixth largest overall burden of the 291 conditions studied at GBD 2010, low back pain caused more disability worldwide than any other condition (HOY et al 2014).

In Brazil, the economic burden of low back pain can be evidenced by the results obtained with the evaluation of the expenditures by the General Social Security System - RGPS revealing an excessive negative socioeconomic impact by the cases of physical incapacity, dismissal of the employees of the work, besides expenses with insurance and treatment (GREVE e AMATUZZI, 2013).

The present article evaluated social security expenditures by the National Social Security Institute (INSS) during the period from 2008 to 2014 in Brazil, related to CIDs M54 and M51. The benefits analyzed were: accidental disease aid, retirement due to accident, disease aid and disability retirement. The Brazilian population in the period under study was 190.732 .694 people, of these $84.4 \%$ living in urban areas, according to the latest demographic census released by the Brazilian Institute of Geography and Statistics (IBGE) in 2010 (INSTITUTO BRASILEIRO DE GEOGRAFIA E ESTATÍSTICA, 2010). Federal public health expenditures ranged from 1.6\% in 2008 to $1.7 \%$ of Brazil's Gross Domestic Product (GDP) in 2014, while pension benefit spending was $6.9 \%$ of GDP in 2014, reaching $7.4 \%$ in 2015 (RELATÓRIO DE ANÁLISE ECONÔMICA DOS GASTOS PÚBLICOS FEDERAIS, 2017).

Total social security expenditures in the period from 2008 to 2014 with low back pain in Brazil was $\mathrm{R} \$$ 1.553.094.158,00, reaching an annual average of $R \$ 221.870 .594,00$. The total number of beneficiaries was 1.476.414 of which 1.329 .139 were urban residents. The sickness benefit was the most prevalent benefit with an average annual cost of $R \$ 616.209 .578,00$. From projection calculations performed by the authors it can be inferred that that in 2024 the annual social security expenditure with low back pain could reach approximately $R \$ 430.000 .000,00$, burdening the public coffers at around $R \$ 699.000 .000,00$ in 2034 .

The study showed a higher prevalence of low back pain in urban men. Many authors report the presence of low back pain to a set of causes, such as sociodemographic factors (age, sex, income and schooling), health status, lifestyle or behavior (smoking, eating and physical inactivity) and occupation (heavy physical work, repetitive motions). The greater exposure of these individuals to such factors would justify the prevalence of low back pain in this group (FERREIRA et al, 2010).

The main result of this analysis shows that the studies on social security expenditures with low back pain, conducted with samples from the Brazilian population, present significant limitations since they do not include the benefits of low back pain in the private sector. In addition, another limitation is the short period of time (2008 to 2014) of research on the extent of the economic impact that this pathology generates to the Brazilian pension system.

\section{CONCLUSIONS}

From the study of the collected data, it is possible to infer that low back pain is a disease of great social and economic impact in the country. According to data presented by the INSS, during the years 2008 to 2014 , referring to the expenses with low back pain, it can be deduced that the sickness aid was the category that required greater financial resources of the country to be supplied, adding an amount in the value of $R \$$ 619.209.578. It can also be included that the costly costs mainly refer to the male beneficiaries coming from the urban area. For a broader scope of work and its results regarding the cost of benefits granted to patients with low back pain in Brazil, studies will be required that contemplate the private pension system, as well as the number of beneficiaries. 


\section{REFERENCES}

1. CORDEIRO GF. O regime geral de previdência social: diagnósticos estruturais críticos e propostas de reformas (Dissertação de Mestrado em administração pública)-Escola Brasileira de Administração Pública e de Empresas (EBAPE). Fundação Getúlio Vargas, Rio de Janeiro; 2006.

2. REIS PF, MORO AR, CONTIJO LA. A importância da manutenção de bons níveis de flexibilidade nos trabalhadores que executam suas atividades laborais sentados. Revista Produção Online, 2003; 3(3):1676-1901.

3. MADEIRA HGR, GARCIA, JBS, LIMA MVV et al. Incapacidade e fatores associados à lombalgia durante a gravidez. Revista Brasileira de Ginecologia e Obstetrícia, 2013; 35(12): 541-548.

4. WALKER BF. The prevalence of low back pain: a systematic review of the literature from 1966 to 1998. Journal of Spinal Disorder, 2000; 13:205-17.

5. HOY D, BAIN C, WILLIAMS G et al. A systematic review of the global prevalence of low back pain. Arthritis Rheumatoid, 2012; 64:2028-37.

6. FERREIRA ML, MACHADO G, LATIMER J et al. Factors defining care-seeking in low back pain: a meta-analysis of population based surveys. European Journal of Pain, 2010; 14:747.e1-.e7.

7. ABREU ATJB, RIBEIRO CAB, Prevalência de lombalgia em trabalhadores submetidos ao programa de reabilitação profissional do Instituto Nacional do Seguro Social (INSS). Acta Fisiátrica, 2010; 17(4): 148-152.

8. DEYO RA, CHERKIN D, CONRAD D et al. Cost, controversy, crisis: low back pain and the health of the public. Annual. Review of Public Health, 1991; 12:141-56

9. Instituto de Métrica e Avaliação em Saúde. Estudo de carga de doença global: gerando evidências, informando políticas de saúde. Seattle, WA. Seatle: Institute for Health Metrics and Evaluation; 2013; 5-29 p.

10. BUCHBINDER R, BLYTH FM, MARCH LM et al. Placing the global burden of low back pain in context. Best Practice \& Research Clinical Rheumatology, 2013;27(5): 575-589.

11. HOY D, MARCH L, BROOKS $P$ et al. The global burden of low back pain: estimates from the Global Burden of Disease 2010 study. Annals of Rheumatology Disease, 2014; 73:968-974.

12. GREVE JMD, AMATUZZI MM. Medicina de reabilitação aplicada à ortopedia e traumatologia. São Paulo: Roca; 1999. 34 p.

13. Instituto Brasileiro de Geografia e Estatística. Disponível em: <http://IBGE.gov.br/senso2010> Acesso em: 10 out. 2017.

14. Relatório de Análise Econômica dos Gastos Públicos Federais. Evolução dos Gastos Públicos Federais no Brasil: Uma análise para o período 2006-2015. Disponível em: <http://www.fazenda.gov.br/centrais-deconteudos/publicacoes/transparencia-fiscal/analise-economica-dos-gastos-publicosfederais/relatorio gasto publico federal site.pdf $>$. Acesso em: 10 out. 2017.

15. Regime Geral-RGPS. Disponível em: <http://www.previdencia.gov.br/perguntas-frequentes/regime-geral-rgps/>> Acesso em: 10 out. 2017. 